ISSN (Print) : :1412-7601

ISSN (Online) : 2654-8712

Volume 6, No.2 September 2020

EKONOBIS

http://www.ekonobis.unram.ac.id

\title{
Dinamika Kependudukan Provinsi Nusa Tenggara Barat Analisis Parameter Sosio-Demografik
}

\section{Jalaludin. \\ Universitas Mataram ARTICLE INFO}

Keywords :

Population, quantity, quality
ABSTRACT : Demography has two main aspects, i.e. quantity and quality aspects. The two aspects may be studied through their trends, distributions, growth, and compositions. The demographic process, such as fertility, mortality, and migration, on the other hand, are the factors affecting the dynamics of the demographic aspects. This study aimed at analyzing the socio-demographic parameter or the demographic dynamics of NTB. This study specifically analyzed secondary data in which the main data came from the series of result of the Population Census conducted by the Central Bureau of Statistics. The data analysis was carried out using descriptive method by utilizing the statistical tables and graphs to find the trend or the development of the parameter taken as the analytical object. According to the result of the analysis, it could be concluded that: a) the Population Growth Rate of NTB had sharply decreased during the last 5 decades, even to the extent of becoming the fifth lowest in Indonesia. However, the distribution was uneven in which most of the population (70\%) were concentrated in Lombok Island, whose size is only a quarter of the whole area of NTB; b) the gender ratio of NTB population was the lowest in Indonesia, i.e. 94.26 compared to the national average which reached 101.37 ; c) the Total Fertility Rate (TFR) dropped from 7.0 to 2.4 during the last 5 decades and the most drastic decrease was recorded during the decade of 1990-2000 in which the TFR dropped as much as $61.3 \%$ from 5.0 to 3.0. Likewise, the Infant Mortality Rate dropped from 221 per 1000 live births to 48 ; d) the quality of NTB population reflected by the Human Development Index (IPM, Indeks Pembangunan Manusia) was very low which was the third lowest in Indonesia. Besides, there was a gap of IPM among the municipalities/regencies in which Mataram City and Bima City had the IPM far above the provincial rate while the other regencies had far below the provincial rate of IPM.

Kata Kunci :

Demografi, Kuantitas, Kualitas.
ABSTRAK: Penduduk memiliki dua matra utama yaitu aspek kuantitas dan kualitas dimana kedua aspek ini dapat dikaji dengan melihat tren, persebaran, pertumbuhan dan komposisinya. Sementara proses demografi seperti fertilitas, mortalitas dan migrasi merupakan factor-factor yang mempengaruhi dinamika dari aspek kependudukan tersebut. Penelitian ini bertujuan untuk menganaisis parameter sosiodemografik kependudukan di Provinsi Nusa Tenggara Barat (NTB). Penelitian ini sepenuhnya menganalisis data sekunder dimana data utama bersumber dari rangkaian data Sensus Penduduk yang dilaksanakan oleh Badan Pusat Statistik (BPS). Sementara analisis data dilakukan dengan metode deskriptif dengan memanfaatkan tabel statistik dan grafik untuk melihat tren atau perkembangan dari parameter yang menjadi objek analisis. Berdasarkan hasil analisis disimpulkan bahwa 1) Laju pertumbuhan penduduk (LPP) NTB mengalami penurunan yang cukup tajam dalam 3 dekade terakhir, bahkan mencapai terendah kelima di Indonesia, namun sebarannya tidak merata di mana sebagian besar (70 persen lebih) penduduk terkonsentrasi di pulau Lombok yang luasnya sekitar seperempat dari luas wilayah NTB. 2) Rasio jenis kelamin penduduk NTB terendah di Indonesia yakni 94,26 dibandingkan dengan rata-rata nasional yang mencapai 101,37. c) Total Fertility Rate (TFR) turun dari 7,0 menjadi 2,4 selama lima decade terahir dan penurunan paling drastis tercatat pada periode 1990-2000 dimana TFR turun sebesar 61,3 persen dari 5,0 menjadi 3,1 persen, demikian juga Angka Kematian Bayi (AKB) menurun tajam dari 221 per 1000 kelahiran hidup menjadi 48 per 


\begin{tabular}{l}
\hline \\
$\qquad \begin{array}{l}\text { seribu kelahiran hidup, d) kualitas penduduk NTB yang dicerminkan oleh Indeks } \\
\text { Pembangunan Manusia (IPM) tergolong rendah yaitu berada pada peringkat ketiga } \\
\text { terbawah dari seluruh provinsi di Indonesia. Selain itu terjadi kesenjangan IPM antar } \\
\text { kabupaten/kota dimana kota Mataram dan kota Bima memiliki IPM jauh di atas rata- } \\
\text { rata provinsi sementara kabupaten lain IPM-nya jauh di bawah rata-rata provinsi. }\end{array}$ \\
\hline Corresponding Author : \\
Alamat : Program Studi Ekonomi Pembangunan, Fakultas Ekonomi dan Bisnis, Universitas Mataram, Jln. Majapahit No. \\
e-mail: Jalaludin@unram.ac.id
\end{tabular}

2020, EKONOBIS All right reserved 


\section{PENDAHULUAN}

\section{Latar Belakang}

Secara kuantitas jumlah penduduk Indonesia adalah keempat terbesar di dunia setelah Cina, India dan Amerika Serikat, dengan laju pertumbuhan yang masih relatif tinggi, yaitu 1,49 persen. Sementara dari segi kualitas, penduduk Indonesia masih tergolong rendah yang diindikasikan oleh tingkat pendidikan yang relative rendah, angka kemiskinan tinggi, tingkat kematian yang masih cukup tinggi dan secara umum Indeks Pembangunan Manusia (IPM) yang masih rendah. Indeks Pembangunan Manusia (IPM) Indonesia berada pada urutan ke 6 dari 11 negara ASEAN yaitu 0,707, dibawah Singapura, Brunai Darussalam, Malaysia, Thailand dan Filipina.

Indeks Pembangunan Manusia (IPM) Negara Asean 2019

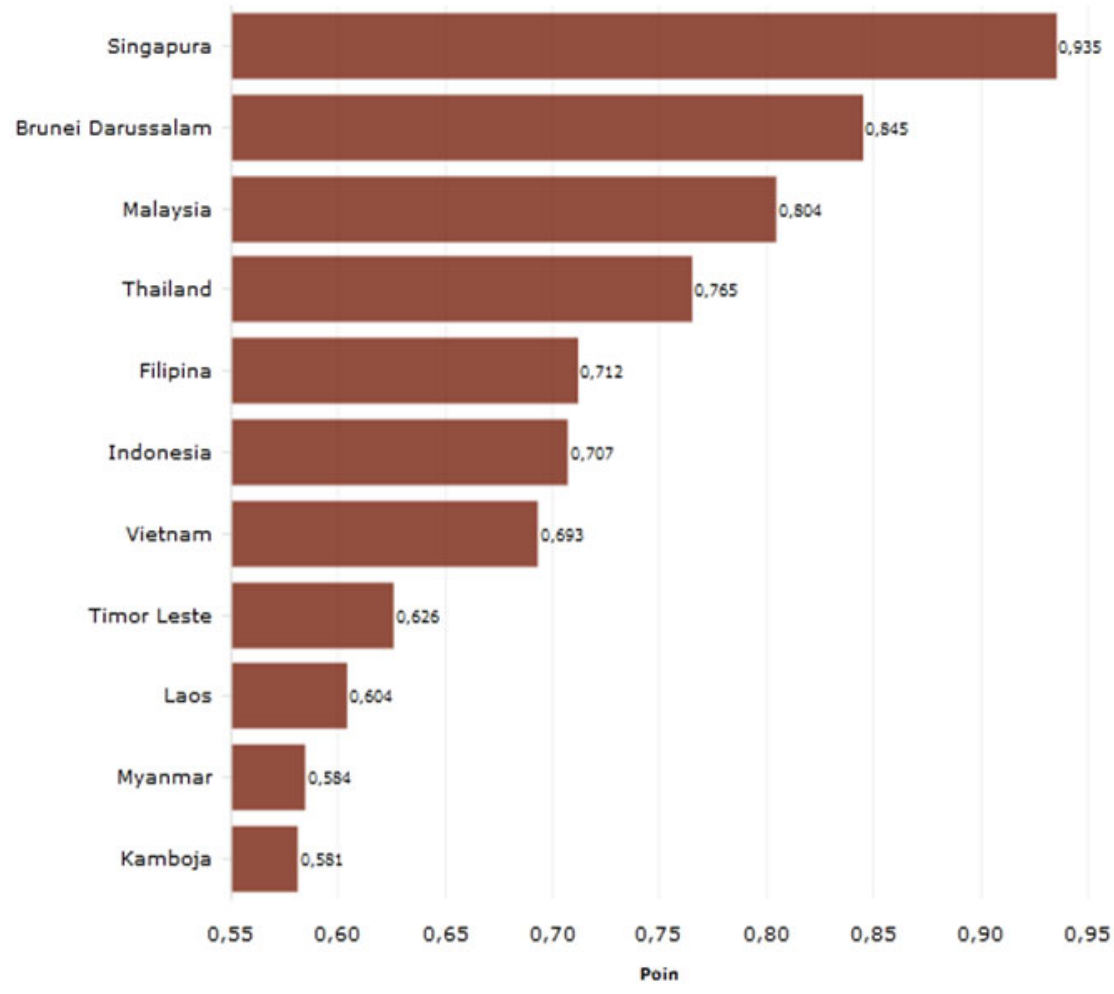

Selain masalah kuantitas dan kualitas yang tidak merata dan berjejal di suatu penduduk, Indonesia juga dihadapkan wilayah, akan memberikan tekanan beban pada persoalan distribusi atau persebaran penduduk yang tidak merata. Sebagian yang berat bagi wilayah bersangkutan, termasuk masalah lingkungan besar (lebih dari 70 persen) penduduk (envirounmental stress), seperti Indonesia tinggal di pulau Jawa yang kerusakan hutan, kerusakan terumbu luasnya hanya sekitar 7 persen dari luas karang, masalah air bersih (water wilayah Indonesia. Distribusi penduduk management), sampah, pendangkalan 
sungai sampai pada persoalan polusi udara yang parah.

Sebenarnya jumlah penduduk yang besar, bila diikuti dengan kualitas yang baik, produktif, maju dan mandiri, akan dapat menjadi modal pembangunan. Namun jika tidak, jumlah penduduk yang besar akan menjadi beban berat bagi usaha meningkatkan kesejahtraan rakyat dan upaya mewujudkan keadilan social bagi seluruh rakyat Indonesia sebagaimana diamantkan dalam UUD 1945. Disisi lain pertumbuhan penduduk yang besar memang tidak semata- mata akibat tingginya angka kelahiran, tetapi juga dipengaruhi oleh peningkatan usia harapan hidup (UHH), sejalan dengan semakin membaiknya tingkat kesehatan penduduk. Namun usaha yang lebih manusiawi adalah lebih baik mengendalikan angka kelahiran dari pada membiarkan angka kematian tinggi.

Penomena kependudukan seperti diuraikan di atas, merupakan penomena yang terjadi secara nasional, yang mencerminkan kondisi kependudukan secara keseluruhan diseluruh provinsi. Secara spesifik boleh jadi trend kependudukan secara nasional tersebut bisa sama atau juga bisa berbeda sangat bergantung pada kondisi dan dinamika factor- factor yang mempengaruhi variable kependudukan tersebut. Terkait dengan persoalan tersebut, maka tulisan ini mencoba untuk mengungkap dinamika kependudukan NTB, terkait dengan aspek kuantitas dan kualitas penduduk, yang meliputi: 1).Jumlah dan laju pertumbuhan serta persebaran penduduk, 2). Struktur penduduk menurut kelompok umur dan jenis kelamin, 3). Perkembangan tingkat Fertilitas dan Mortalitas 4). Indikator kualitas penduduk.

\section{KAJIAN PUSTAKA}

Parameter demografi yang dimaksudkan dalam penelitian ini adalah ukuran-ukuran yang digunakan untuk melihat struktur dan proses penduduk di suatu wilayah yang dalam hal ini adalah NTB. Struktur penduduk meliputi jumlah, pertumbuhan, sebaran dan komposisi penduduk. Struktur penduduk bersifat dinamis, selalu berubah karena adanya proses demografi yang menyertainya. Proses demografi dimaksud meliputi kelahiran, kematian dan migrasi atau perpindahan penduduk. Selain ketiga faktor tersebut, struktur penduduk juga dipengaruhi oleh faktor lain seperti perkawinan dan perceraian. Perubahan dalam struktur yang menyangkut prubahan dalam jumlah maupun 
komposisi penduduk akan membawa dampak atau pengaruh terhadap perubahan sosial, ekonomi dan politik bagi penduduk yang tinggal di suatu wilayah.

Menurut Multilingual Demographic Dictionary: Demography is the scientific study of human population in primarily with the respect to their size, their structure (composition), and their development (change). (Demografi adalah ilmu yang mempelajari perkembangan penduduk suatu wilayah terutama mangenai jumlah, struktur (komposisi) dan perkembangan (perubahannya).

Sedangkan menurut Hauser dan Duncan (dalam Umi Listyaningsih, 2016): Demography is the study of the size, territorial distributions and composition, changes there in and the components af such changes wich maybe identified as nataly, mortality territorial movement (migrations), and sosial mobility (changes of states) (Demografi mempelajari jumlah, persebaran, territorial dan komposisi penduduk serta perubahanperubahannya, serta sebab-sebab dari perubahan tersebut yang biasanya ditimbulkan oleh natalitas (fertilitas), mortalitas, migrasi dan mobilitas sosial (perubahan status kearga nwgaraan). Dari kedua definisi tersebut di atas, dapat disimpulkan bahwa demografi adalah mempelajari struktur dan proses penduduk di suatu wilayah. Struktur penduduk dalam hal ini meliputi jumlah, persebaran dan komposisi penduduk. Struktur penduduk senaniasa berubah yang disebabkab karena proses demografi yaitu adanya kelahiran (Fertility), kematian (mortality) dan migrasi penduduk.

Konsep demografi terus mengalami perkembangan dan para ahli memberikan sudut pandang yang berbeda dari setiap konsep yang berikan. Methors dan Sirks misalnya membedakan masalah penduduk mejadi dua yaitu yang terkait dengan jumlah (kuantitas) dan yang terkait dengan masalah kualitas, sementara Adolphe Loundry (Anonimous, 2015) memberikan istilah demografi yang bersifat analitis matematis yang dapat menghasilkan teknik-teknik untuk menghitung data kependudukan.

\section{METODE PENELITIAN}

Penelitian ini merupakan kajian atau analisis data sekunder dimana data 
utama bersumber dari rangkaian hasil Sensus Penduduk yang dilaksanakan oleh Badan Pusat Statistik (BPS). Data tersebut antara lain meliputi jumlah penduduk, laju pertumbuhan, persebaran dan struktur penduduk menurut kelompok umur dan jenis kelamin. Parameter demografik lainnya yang ditelaah mencakup fertilitas, mortalitas serta usia harapan hidup penduduk NTB. Selain itu dilakukan kajian terhadap indikator kualitas penduduk dimana datanya tidak hanya bersumber dari hasl Sensus Penduduk dan Supas tetapi juga dari data Susenas. Analisis data dilakukan dengan metode deskriptif dengan memanfaatkan tabel statistik dan grafik untuk melihat tren atau perkembangan parameter kependudukan.

\section{PEMBAHASAN}

1.Jumlah, Persebaran dan Laju

\section{Pertumbuhan Penduduk NTB}

Persoalan kependudukan di NTB tidak jauh berbeda dengan persoalan kependudukan secara nasional dimana selain jumlah penduduknya yang relative besar dan persebarannya yang tidak merata, juga struktur penduduknya didomnasi oleh kelompok umur usia muda dan anak- anak.
Jumlah penduduk NTB tahun 2019 sebanyak 5.013.687 jiwa, terdiri dari 2.433.731 laki- laki dan 2.579.956 perempuan. Kontribusi penduduk NTB secara nasional adalah 1,9 persen terhadap penduduk Indonesia secara keseluruhan. Dengan jumlah penduduk sebanyak itu menempatkan NTB terutama pulau Lombok menjadi salah satu pulau yang memiliki penduduk terpadat di Indonesia setelah pulau jawa dan Bali.

Persebaran penduduk NTB tergolong timpang karena dari 5.013 .687 jiwa penduduk 70,41 persen tinggal di pulau Lombok sementara sisanya 28,59 persen mendiami pulau Sumbawa, padahal pulau Lombok luasnya hanya sepertiga dari luas pulau Sumbawa. Demikian pula persebaran penduduk perkabupaten kondisinya tidak jauh berbeda dimana dari 10 kabupaten kota yang ada di NTB kabupaten Lombok Timur merupakan kabupaten dengan jumlah penduduk terbesar dan disusul kemudian oleh kabupaten Lombok Tengah dimana jumlah penduduk kedua kabupaten ini mencapai 43 persen dari seluruh penduduk NTB. Sementara kabupaten Sumbawa Barat merupakan kabupaten dengan jumlah penduduk terkecil di NTB. 
Tabel 1: Jumlah dan Persebaran Penduduk NTB, 2019.

\begin{tabular}{|l|l|l|l|}
\hline No & Kabupaten/ Kota & Jumlah Penduduk & Persebaran (\%) \\
\hline 1 & Lombok Barat & 685,161 & 13.33 \\
\hline 2 & Lombok Tengah & 839,409 & 19.11 \\
\hline 3 & Lombok Timur & $1,192,110$ & 24.57 \\
\hline 4 & Sumbawa & 453,797 & 9.24 \\
\hline 5 & Dompu & 248,879 & 4.87 \\
\hline 6 & Bima & 483,901 & 9.76 \\
\hline 7 & Sumbawa Barat & 144,707 & 2.55 \\
\hline 8 & Lombok Utara & 218,533 & 4.45 \\
\hline 9 & Mataram & 447,476 & 8.95 \\
\hline 10 & Kota Bima & 169,714 & 3.17 \\
\hline Pulau Lombok & $3,530,137$ & 70.41 \\
\hline Pulau Sumbawa & $1,483,550$ & 29.59 \\
\hline Nusa Tenggara Barat & $5,013,687$ & 100.00 \\
\hline
\end{tabular}

penduduk perkotaan baru mencapai 17,1

Persebaran penduduk NTB berdasarkan tipe daerah (desa-kota), menunjukkan bahwa penduduk perkotaan menunjukkan trend yang meningkat. Proporsi penduduk perkotaan di NTB mencapai 41,7 persen, dan kota Mataram menjadi satu-satunya wilayah di NTB yang seluruh penduduknya tinggal di perkotaan, sementara kota Bima baru mencapai 78,6 persen. Proporsi penduduk perkotaan di NTB terus mengalami peningkatan dari 8,1 persen tahun 1971 menjadi 41,7 persen tahun 2010 atau meningkat sekitar lima kali lipat dalam empat dekade. Pada tahun 1990 proporsi persen, meningkat dua kali lipat menjadi 34,8 persen pada tahun 2000 atau bertambah 103,5 persen dalam satu dekade (1990-2000). Pesatnya laju urbanisasi ini disebabkan selain karena banyaknya pemekaran wilayah perkotaan yang terjadi sejak tahun 1990-an, juga banyaknya masyarakat atau penduduk perdesaan yang bermigrasi ke perkotaan untuk mencari pekerjaan serta pertumbuhan penduduk perkotaan itu sendiri. 
Gambar 1. Tren Urbanisasi NTB Berdasarkan data

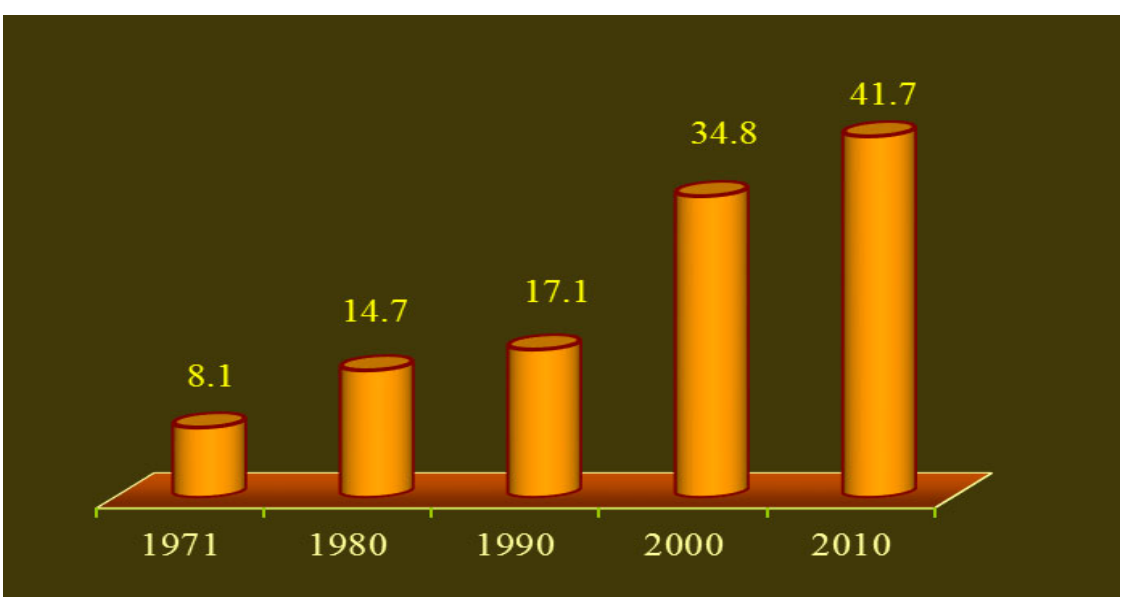

Laju pertumbuhan penduduk (LPP) NTB dalam kurun waktu beberapa dekade terahir menunjukkan tren yang menurun. Pada periode tahun 1971- 1980, pertumbuhan penduduk NTB masih tinggi yaitu mencapai 2,36 persen. Sepuluh tahun kemudian yaitu periode 1980- 1980 pemerintah daerah mampu menurunkan LPP NTB menjadi 2,15 persen dan menjadi 1,29 persen pada periode $1990-$ 2000. Berdasarkan SP 2010 laju pertumbuhan penduduk NTB mencapai angka 1,17 lebih rendah dibanding LPP Indonesia sebesar 1,47 sekaligus menempatkan NTB sebagai provinsi dengan LPP terrendah ke lima secara nasional.

Gambar 2. LPP NTB Berdasarkan data SP 1971-2010

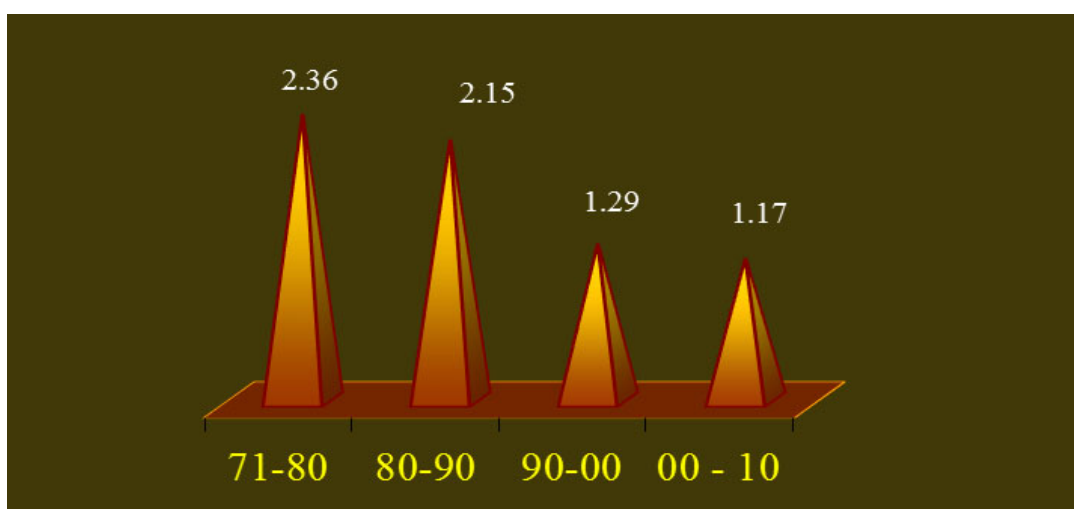

Sementara kalau kita lihat laju Penurunan LPP ini menunjukkan bahwa pertumbuhan penduduk berdasarkan program pemerintah dalam hal kabupaten, penurunan LPP NTB cukup pengendalian laju pertumbuhan merata kecuali di kabupaten Lombok penduduk relatif berhasil.

Barat dan kabupaten Bima yang masih 2. Struktur Penduduk NTB menunjukkan tren yang meningkat. 
Struktur penduduk NTB sebagaimana terlihat dalam piramida penduduk di bawah ini memperlihatkan bahwa sebahagian besar penduduk berada pada kelompok umur 0-4 tahun, 5-9 tahun dan 10-14 tahun yaitu sebanyak 1.828 .433 jiwa atau 40,63 persen dari jumlah penduduk NTB. Dengan demikian dapat dikatakan bahwa struktur penduduk NTB

Gambar 3: Piramida Penduduk NTB Berdasarkan data SP, 1971-2010

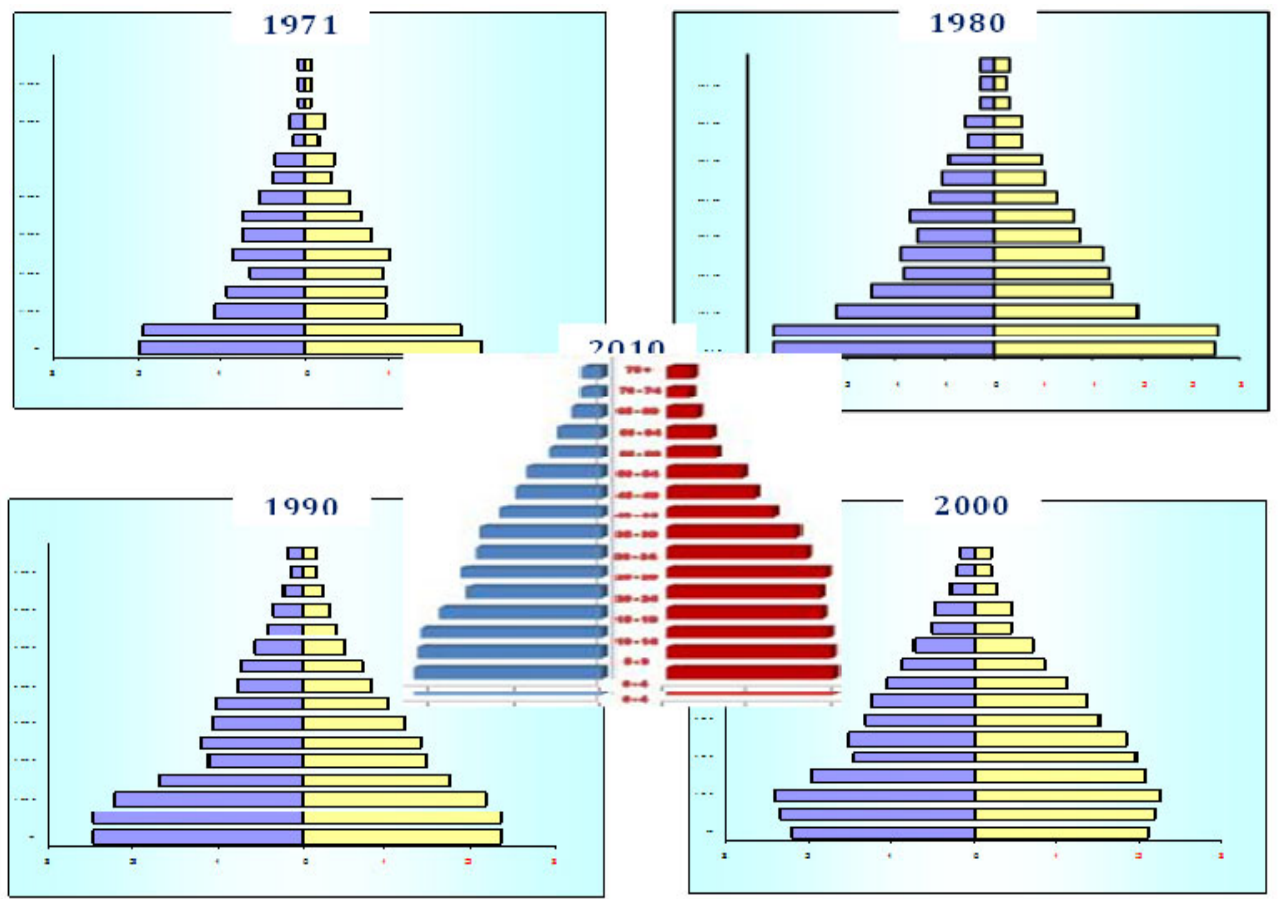

Selain didominasi oleh penduduk usia muda, struktur penduduk NTB juga ditunjukkan oleh lebih banyaknya penduduk perempuan dibandingkan penduduk laki-laki terutama pada kelompok usia produktif muda dan pada usia lanjut. Rasio jenis kelamin yang ideal tentulah rasio jenis kelamin yang tidak terlalu pincang dimana dalam setiap kelompok umur jumlah penduduk laki-laki adalah didominasi oleh kelompok umur muda. Akibat dari terkonsentrasinya penduduk pada usia muda ini menyebabkan beberapa konsekwensi diantaranya adalah menyangkut aspek ekonomi dan pemenuhan hidup keluarga, aspek pemenuhan gizi, pendidikan dan kebutuhan lainnya. 
angkatan kerja. Rasio jenis kelamin kemudian kembali mendekati keseimbangan pada kelompok umur 55-
59 tahun dan setelah itu kembali menurun.

Gambar 4: Pola Sex Ratio Menurut Kelompok Umur Menurut Data SP 2010 di NTB

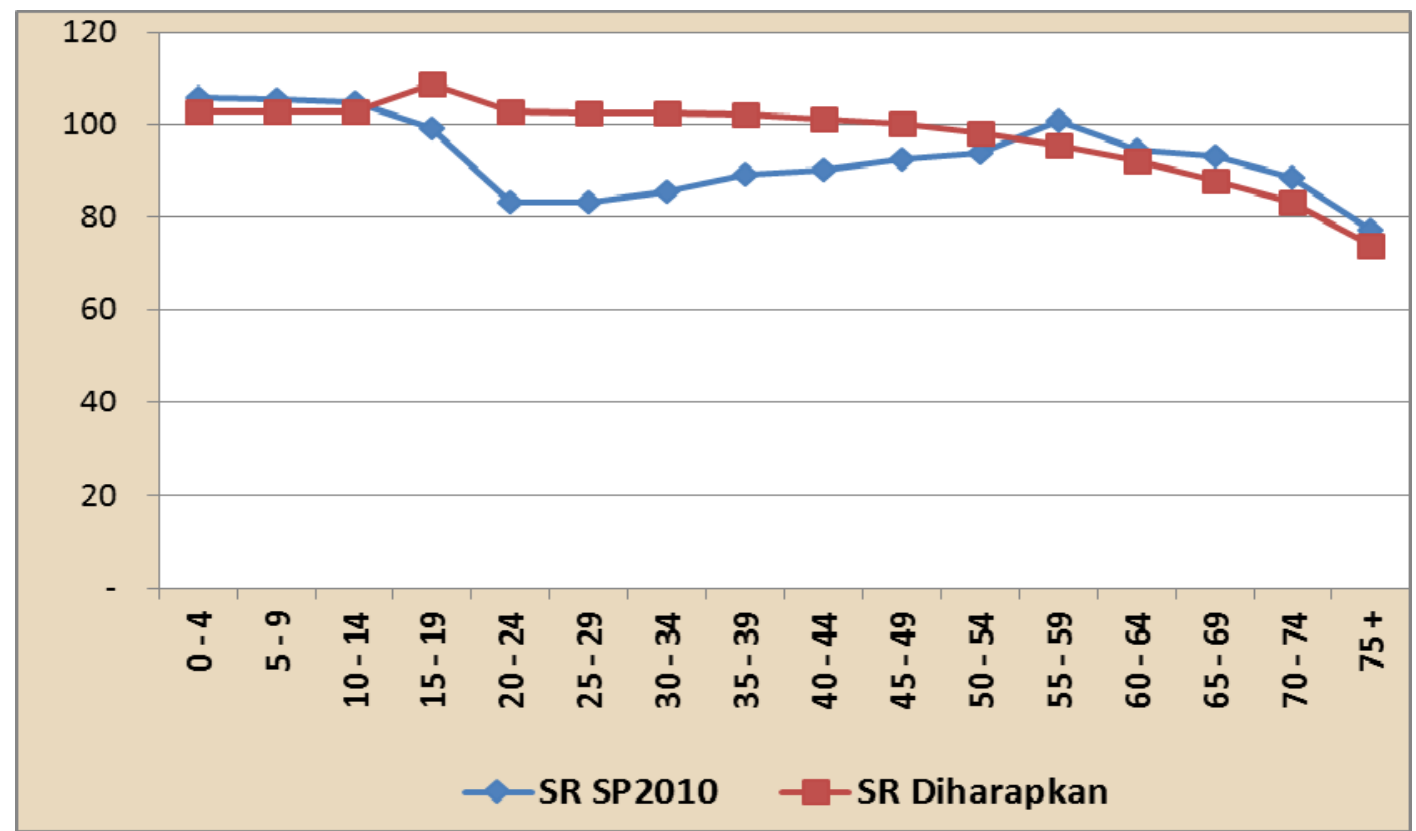

Menumpuknya penduduk pada kelompok

umur anak-anak dan usia muda membawa dampak terhadap ratio beban ketergantungan penduduk. Berdasarkan data SP 2010 rasio beban ketergantungan penduduk NTB adalah 55,55 yang berarti setiap 100 orang penduduk produktif di NTB menanggung sebanyak 56 orang penduduk yang tidak produktif.

\section{Perkembangan Tingkat Fertilitas dan Mortalitas}

Fertilitas merupakan hasil reproduksi riil dari seorang wanita atau sekelompok wanita, juga bisa didefinisikan sebagi banyaknya anak yang dilahirkan dalam keadaan hidup. Sementara mortalitas atau kematian adalah hilangnya tandatanda kehidupan secara permanent. Mortalitas bisa disebabkan karena aspek degenerative seperti penyakit cardiovascular, juga bias disebakan oleh penyakit infeksi yaitu penyakit yang dapat menular dari satu orang ke orang lain seperti pneumonia, TBC, influenza, syphilis dan lain-lain, atau juga bisa karena faktor lingkungan sosial dan ekonomi. Perkembangan tingkat fertilitas (TFR) di NTB dari berbagai data sensus, cukup menggembirakan dimana trennya menunjukkan penurunan yang cukup signifikan. 
Gambar 5: Tren Tingkat Fertilitas (TFR) NTB Berdasarkan data SP 1971-2010

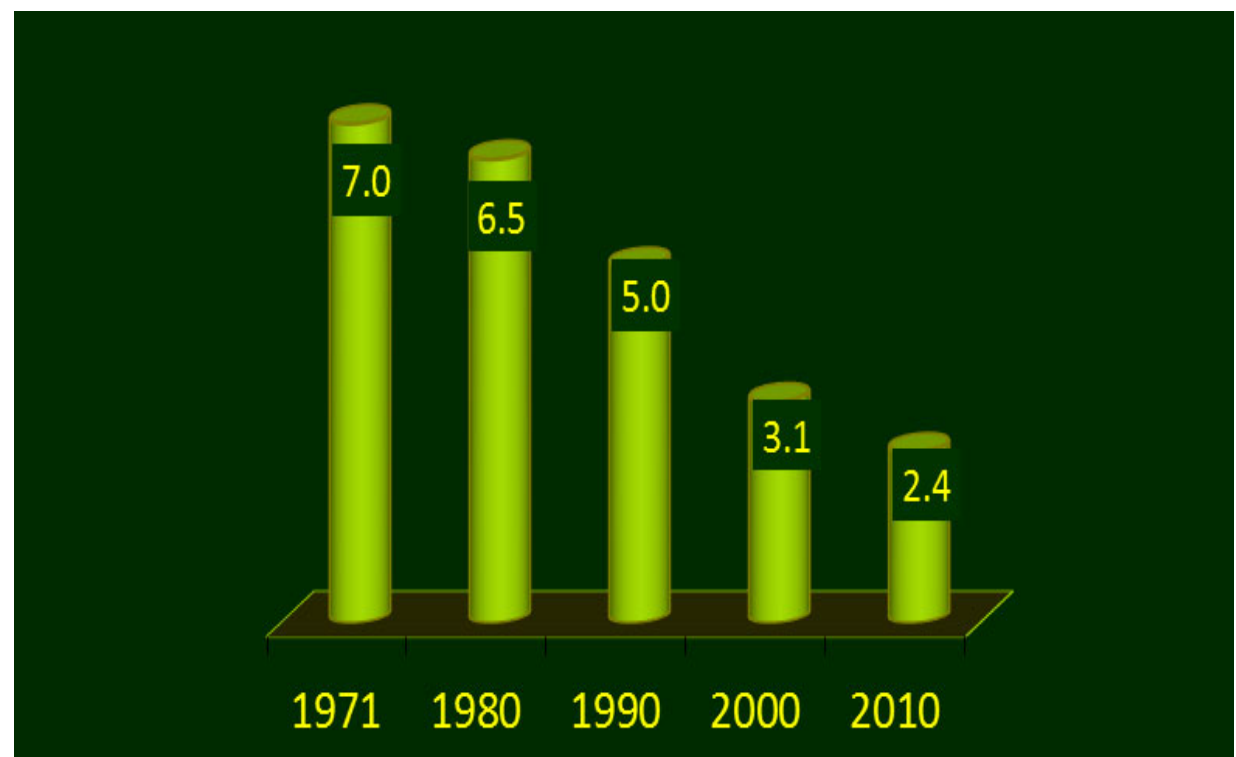

Perkembangan fertilitas NTB sejak tahun 1971-2010 menunjukkan bahwa TFR NTB mengalami penurunan yang drastis. TFR NTB pada tahun 1971 mencapai 7 per wanita, menurun menjadi 6,5 pada tahun 1980. Penurunan yang sangat tajam terjadi pada kurun waktu 1990-2000 yaitu dari rata-rata 5 per wanita menjadi 3,1 per wanita. Hal ini terjadi berkat keberhasilan program KB pada saat itu dimana pada periode tersebut NTB tercatat secara nasional sebagai salah satu provinsi yang berhasil dalam mengendalikan penduduk melalui program Keluarga Berencana.
Disamping mampu menurunkan tingkat fertilitas (TFR), pemerintah NTB juga berhasil menurunkan angka kematian bayi. Kalau Sensus Penduduk pertama tahun 1971 angka kematian bayi (AKB) di NTB sangat tinggi yaitu mencapai 221 kematian per 1000 kelahiran hidup, secara bertahap angka tersebut mampu diturunkan hingga menjadi 48 per 1000 kelahiran hidup. Penurunan terpesat terjadi pada kurun waktu 1990-2000 dimana AKB turun dari 145 menjadi 75 per 1000 kelahiran hidup atau turun 93,3 persen. 
Gambar 6: Tren Angka Kematian Bayi (AKB) dan Usia Harapan Hidup (UHH)

NTB Berdasarkan data SP, 1971-2010

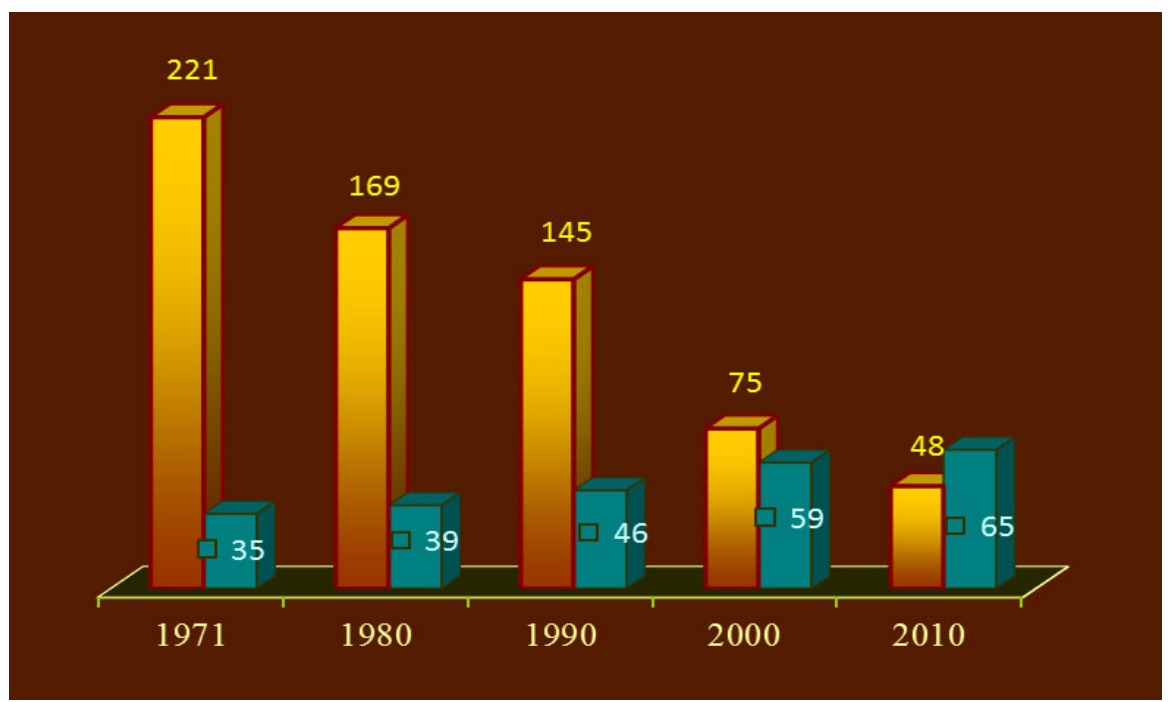

Seiring dengan menurunnya tingkat fertilitas (TFR) dan angka kematian bayi $(\mathrm{AKB})$, angka harapan hidup $(\mathrm{AHH})$, juga meningkat. Jika dulu ada semacam anekdot yang menyatakan" kalau mau berumur pendek maka hiduplah di NTB dan kalau mau berumur panjang maka tinggallah di Yogyakarta", maka hal tersebut tampaknya tidak berlaku lagi, karena sekarang angka harapan hidup NTB juga cukup tinggi tidak terlalu jauh berbeda dengan angka rata-rata nasional maupun Yogyakarta. Pada tahun 1971 usia harapan hidup NTB sangat rendah dan terendah di Indonesia yaitu 35 tahun pada SP 1971. Secara bertahap angka harapan hidup berhasil di tingkatkan hingga mencapai 65 tahun atau meningkat 85,7 persen selama hampir empat dekade.
4.Indikator Kualitas Penduduk: Indeks Pembangunan Manusia

Kualitas penduduk mencakup kualitas fisik dan kualitas non-fisik. Kualitas fisik meliputi sedikitnya tiga indikator yaitu gizi/ukuran antropometrik (tinggi, berat badan dan lainnya), kesehatan serta kesegaran jasmani. Kualitas non-fisik dapat berupa kecerdasan, kesehatan mental, pendidikan, religiusitas dan lainlain. Pengukurannya dapat dibedakan atas indikator individu dan kelompok/agregat. Indikator individu menunjukkan kualitas yang melekat pada masing-masing individu. Kualitas kelompok menunjukkan kualitas rata-rata sekumpulan manusia yang menjadi penduduk suatu wilayah. Ukuran kualitas yang banyak digunakan adalah kelompok/agregat, karena lebih 
mudah dalam evaluasi dan intervensi kebijakan.

Dalam kajian ini, indikator yang digunakan untuk mengukur kualitas penduduk adalah Indeks Pembagunan Manusia (IPM) atau Human Development Index (HDI). Indeks ini semakin populer di Indonesia, sejak dihitung pada pertama kali tahun 1996 walaupun IPM sebenarnya sudah diperkenalkan sejak tahun 1990 melalui serial laporan tahunan berjudul Human Development Report yang diterbitkan oleh UNDP. Capaian IPM Provinsi NTB dalam 10 tahun terakhir cukup menggembirakan dan terus mengalami kemajuan. IPM Provinsi NTB meningkat dari 61,16 pada tahun 2010 menjadi 68,14 pada tahun 2019. Selama periode 2014-2018, IPM Provinsi NTB telah bertambah 2,99 poin dengan status capaian IPM sedang. Laju pertumbuhan IPM NTB Tahun 2018 sebesar 1,08 persen.
Walaupun laju pertumbuhan pada tahun 2018 menurun dibandingkan tahun 2017 yang mencapai 1,17 persen, namun pertumbuhannya masih di atas satu persen dan dapat dikatakan tergolong pertumbuhan tinggi. Jika kecepatan pertumbuhan IPM dapat dipertahankan maka bukan tidak mustahil suatu hari nanti akan dapat mencapai IPM level tinggi. Secara umum IPM Provinsi NTB berada di bawah level Nasional. Selisih IPM Provinsi NTB dengan Nasional pada tahun 2010 masih cukup lebar yaitu sebesar 5,37 poin. Seiring dengan berjalannya waktu, selisih ini semakin menipis menjadi 3,78 poin pada tahun 2019. Artinya NTB semakin berbenah dan berusaha mengejar ketertinggalan dengan nasional. Namun sepertinya upaya yang lebih keras diperlukan agar jarak ketertinggalan dengan nasional semakin menipis.

Gambar 7 : Indeks Pembangunan Manusia (IPM) Provinsi NTB dan IPM Nasional 2010- 2019

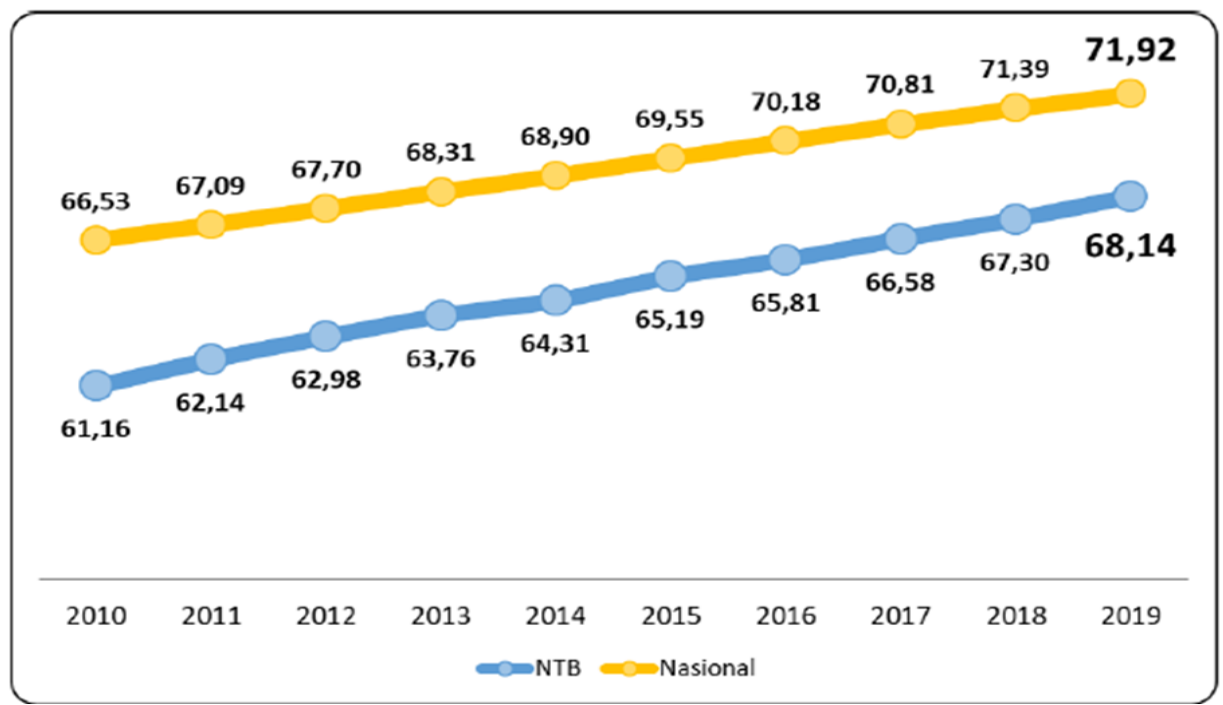


Gambar 7 menunjukkan bahwa IPM provinsi NTB relatif rendah dibandingkan rata-rata nasional. Walaupun terjadi perbaikan kinerja atau percepatan peningkatan IPM dalam 7 tahun terakhir tetapi laju peningkatannya tidak jauh beda dengan laju peningkatan rata-rata nasional. Tabel 9 menunjukkan bahwa IPM tampak mencolok antara kabupaten dan kota dan antar kabupaten di wilayah NTB. Kota Mataram dan Kota Bima mencatat IPM yang jauh di atas rata-rata provinsi dan demikian halnya dengan sejumlah kabupaten di pulau Sumbawa. Tiga kabupaten di pulau Sumbawa mencatat IPM melebihi rata-rata provinsi dan empat kabupaten di pulau Lombok mencatat IPM jauh di bawah rata-rata provinsi. Kabupaten Lombok Utara menempati urutan terendah dalam pencapaian IPM kabupaten/ kota di NTB.

Perkembangan capaian pembangunan manusia di tingkat kabupaten/kota cukup bervariasi. IPM di level kabupaten/kota berkisar antara 64,49 (Kabupaten Lombok Utara) hingga 79,10 (Kota Mataram). Berbeda dengan IPM Provinsi yang berada pada level sedang, beberapa kabupaten/kota di NTB telah berada pada level IPM tinggi. Kota Mataram, Kota Bima dan Kabupaten Sumbawa Barat merupakan kabupaten/kota yang telah mencapai IPM dengan level tinggi, sedangkan kabupaten lainnya masih berada pada level IPM sedang.

Tabel 2 IPM NTB Menurut Kabupaten/ Kota 2010- 2019

\begin{tabular}{|c|c|c|c|c|c|}
\hline Kab/Kota & $\mathbf{2 0 1 5}$ & $\mathbf{2 0 1 6}$ & $\mathbf{2 0 1 7}$ & $\mathbf{2 0 1 8}$ & $\mathbf{2 0 1 9}$ \\
\hline Lombok Barat & $\mathbf{6 4 , 6 2}$ & 65,81 & 66,37 & 67,18 & 68,03 \\
\hline Lombok Tengah & $\mathbf{6 2 , 7 4}$ & 65,55 & 64,36 & 65,36 & 66,36 \\
\hline Lombok Timur & 62,83 & 63,22 & 64,37 & 65,35 & 66,23 \\
\hline Sumbawa & 63,71 & 63,70 & 65,84 & 66,77 & 67,60 \\
\hline Dompu & 64,56 & 65,48 & 66,33 & 66,97 & 67,83 \\
\hline Bumbawa Barat & 63,48 & 64,15 & 65,01 & 65,62 & 66,37 \\
\hline Lombok Utara & 61,15 & 62,24 & 63,04 & 63,83 & 64,49 \\
\hline Mataram & 76,37 & 77,20 & 7,84 & 78,43 & 79,10 \\
\hline Kota Bima & 72,99 & 73,67 & 74,36 & 75,04 & 75,80 \\
\hline NTB & 65,19 & 65,81 & 66,58 & 67,30 & 68,14 \\
\hline
\end{tabular}


Tabel di atas memperlihatkan bahwa IPM kabupaten/ kota di NTB dalam kurun waktu lima tahun terahir menunjukkan trend meningkat di seluruh kabupaten/ kota yang ada di NTB. Walaupun terjadi peningkatan, namun komposisi dalam arti urutan tinggi rendahnya capaian IPM di masing- masing kabupaten/ kota relative tidak berubah. Kota Mataram, Kota Bima dan Kabupaten Sumbawa Barat adalah tiga kabupaten/ kota dengan IPM tertinggi dan tak tergeserkan posisinya dalam lima tahun terahir. Sementara kabupaten Lombok Utara, kabupaten Bima dan Lombok Timur merupakan tiga kabupaten yang memiliki IPM terendah dari 10 kabupaten/ kota yang ada di NTB.

\section{KESIMPULAN}

1. Laju pertumbuhan penduduk (LPP) NTB mengalami penurunan yang cukup tajam dalam 3 dekade terakhir, bahkan mencapai terendah kelima di Indonesia. LPP NTB dibandingkan Indonesia adalah 1,17: 1,47. Namun demikian persebaran penduduk tidak merata di mana sebagian besar (lebih dari 70 persen) penduduk terkonsentrasi di pulau Lombok yang luasnya hanya sekitar seperempat dari luas wilayah NTB.
2. Rasio jenis kelamin penduduk NTB terendah di Indonesia yakni 94,26 dibandingkan dengan rata-rata nasional yang mencapai 101,37 . Rasio jenis kelamin juga teridentifikasi rendah pada segmen penduduk usia 20-34 tahun dan segmen penduduk lanjut usia (65+ tahun).

3. Tingkat fertilitas atau Total Fertility Rate (TFR) menurun derastis selama lima decade terahir yaitu dari 7,0 menjadi 2,4. Demikian pula Angka Kematian Bayi (AKB) menurun tajam dari 221 per 1000 kelahiran hidup pada menjadi 48 per seribu kelahiran hidup.

4. Kualitas penduduk NTB yang diukur berdasarkan Indeks Pembangunan Manusia (IPM) tergolong masih rendah Hal ini ditunjukkan oleh IPM NTB yang masih berada pada pringkat tiga terbawah dari seluruh provinsi yang ada di Indonesia. Selain itu terjadi kesenjangan IPM antar kabupaten/kota dimana kota Mataram dan kota Bima memiliki IPM jauh di atas rata-rata provinsi sementara kabupaten lain IPM-nya jauh di bawah rata-rata provinsi. Namun demikian IPM NTB menunjukkan trend yang meningkat. 


\section{DAFTAR PUSTAKA}

Agus Joko Pitoyo, 2018, Indikator Mortalitas dan Morbiditas. Yogyakarta, BKKBN dan Pusat Studi Kependudukan dan Kebijakan Universitas Gajah Mada.

Badan Pusat Statistik NTB, 2011, Data dan Tabel Hasil Pengolahan Sensus Penduduk 2010. BPS NTB, Mataram.

Badan Pusat Statistik NTB, 2019. Tabel Indeks Pembangunan Manusia NTB 2014-2019. BPS NTB, Mataram.

BPS, Bappenas dan UNDP, 2018. Indonesa Human Development Report 2017: Towards a New Concensus. Published jointly by BPS, Bappenas dan UNDP Indonesia, Jakarta.

Morris, D. M., (1979), Measuring the Condition of the World's Poor: the Physical Quality of Life Index, Pergamon, New York.

Muhajir Darwin, 2015. Dinamika Kependudukan \& Penguatan Governance, Yogyakarta, Media Wacana.

NTB Dalam Angkan, 2019, Badan Pusat Statistik Nusa Tenggara Barat (NTB)

Tukiran dkk, 2010, Akses Penduduk Miskin Terhadap Kebutuhan Dasar, Yogyakarta, Pusat Studi Kependudukan dan Kebijakan Universitas Gajah Mada.

Umi Listyaningsih, 2012, Teori dan Parameter Fertilitas, Yogyakarta, BKKBN dan Pusat Studi Kependudukan dan Kebijakan Universitas Gajah Mada.

UNDP 1919. Human Development Report 1919. Concept and Measurement of Human Development. Oxford University Press, New York. http://hdr.undp.org/en/reports/global/hdr1919.

UNDP 2000. Human Development Report 2000. Human Right and Human Development. Oxford University Press, New York. http://hdr.undp.org/en/reports/global/hdr2000.

UNDP 2010. Human Development Report 2010. The Real Wealth of Nations: Pathways to Human Development. http://hdr.undp.org/en/reports/global/hdr2010 